Chapter 18

\title{
Air Power in Interagency Operations
}

\author{
James S. Corum
}

Interagency operations have become a major feature of modern conflict. Throughout the Cold War, and especially since the terror attacks of 9/11, the United States and other Western nations have faced an array of unconventional threats and enemies that cannot be effectively countered and defeated by conventional military organisations and methods.

Air power has played a key role in fighting unconventional enemies and in supporting Western nations' own unconventional forces. However, non-conventional conflicts require organisations and doctrines that include personnel and resources outside the military forces and organisations that have evolved over the last sixty years. Interagency organisations contain a mix of civilian and military personnel who focus on a specific mission. A true interagency organisation is not just a military organisation with civilian employees, but is organised into groups and teams based on function and expertise in which personnel from military and civilian agencies are fully integrated, with civilians routinely supervising military personnel and vice-versa. Over time Western nations have developed integrated civilian-military organisations for unconventional conflict, such as the British committee system developed during the Malaya counterinsurgency effort (1948-1957), in which military and civilian personnel working together coordinated the counterinsurgency effort with great success. However, a long evolution was required to reach an interagency system and the United States, with its large forces and resources, has been the major Western power to employ the interagency concept as a major tool on conflict. In recent years the best 
example of using the interagency approach has been the United States' development of the Interagency Task Force, an organisation that plays a central role in current conflicts.

This chapter examines the evolution of the interagency concept in modern conflict and the role that air power has played in interagency operations. It examines the beginnings of air power operations in partnership with civilian agencies in the Cold War that set an early model for the US Air Force (USAF). The interagency concept evolved during the Vietnam War, which saw the first true interagency operations, and was revived to deal with irregular threats to the United States in the war on drugs in the 1990s. Finally, the interagency construct has become an indispensable organisation for waging modern conflict and in each step of the evolution of the concept the role of air power has expanded.

\section{Cold War: air power support to intelligence agencies}

Air Force support to intelligence operations conducting clandestine operations was the foundation of the early interagency operations. In 1943 General Eisenhower, then Supreme Commander of the Allied Forces in the Mediterranean, directed the US Army Air Forces (USAAF) to allocate a small number of bombers and transports to support the resistance forces inside occupied Europe. The Office of Strategic Services (OSS), which directed support to anti-Nazi partisans mainly in France, Italy, and Yugoslavia, required aircraft that could penetrate German-controlled airspace at night and parachute agents and commando teams to work with partisan forces. At times, transport planes would land on rough, clandestine airfields behind the lines to deliver personnel, arms, and supplies. These secret operations required specially trained aircrew as well as modifications to aircraft. To fly alone and at night, and to find drop zones and clandestine airfields (usually, farm fields marked 
with lights and small fires) required exceptional piloting and navigational skills (Moore 1992).

From these small beginnings, the USAAF in Europe eventually fielded a specialist wing of 100 aircraft to support OSS operations behind enemy lines throughout southern and western Europe. The greatest success of the 'Carpetbagger' operations in support of the resistance forces was in supplying and supporting the French resistance in the summer of 1944. The resistance fighters were assisted by small teams of Allied officers and noncommissioned officers (NCOs) who trained the resistance fighters and provided vital liaison. As the Allies fought in Normandy thousands of German troops, including whole divisions, were tied up in fighting the well-supplied French resistance forces in the highlands of south central and eastern France. Resistance units also caused havoc with German road and rail communications (Moore 1992). Across the world in the Burma Theater the USAAF created a similar organisation, the $1^{\text {st }}$ Air Commando Wing, that supported the anti-Japanese Burmese guerrillas deep behind enemy lines.

During the 1944-45 Allied campaign in Burma the air-supplied and -supported guerrilla forces disrupted enemy operations and tied down thousands of Japanese who would otherwise have been deployed against the Allied forces fighting their way into Burma (Y'Blood 2014). In neither case were the air-supported irregular forces a decisive factor in the campaigns, but in both cases these forces made a significant contribution to the Allied victories by disrupting enemy logistics and diverting enemy forces. Despite their success, at the end of World War II these highly specialised air units were disbanded. However, they were soon revived with the onset of the Korean War and the rise of the Soviet threat in Europe, which demonstrated a clear need for the Air Force to assist the civilian intelligence agencies to carry out their clandestine operations. 
The United States created the Central Intelligence Agency (CIA) out of the intelligence agencies formed in World War II in the grand reorganisation of the American national security system in 1947 . The Air Force, which was established as an independent service in 1947, already had a history of providing specialised air support to the OSS, the forerunner to the CIA, during World War II. In the early Cold War period of the 1950s, the USAF and CIA developed a close partnership in order to conduct unconventional operations against Communist states. While not a true interagency model in the current sense, the work of the Air Force in partnering with a civilian agency was an important and essential step in the development of the interagency system used today.

During the Korean War the USAF's special operations force, modeled on the special operations groups formed in World War II, was substantially increased. In the aftermath of the Korean War the US military again reduced the special operations forces, but still maintained a few small and highly secret Air Force units organised to conduct special operations missions for the CIA. At a time when the USAF was oriented around nuclearcapable bombers such as the B-52 and was rapidly developing an intercontinental nuclear missile force, at the other end of the spectrum in the 1950s and 1960s the US Air Force special operations units operated some highly specialised but low-technology equipment such as the SA-16 Albatross flying boat, a simple radial-engine aircraft that cruised at 140 knots, but also had an endurance of sixteen hours and was capable of landing on small bodies of water. With the waters and airspace of the Warsaw Pact countries closely guarded and the land borders heavily mined and patrolled the Albatross flying boat, painted black for night operations and with the exhaust shielded to reduce engine flame, offered the best means of infiltrating agents and exfiltrating defectors and agents from behind the Iron Curtain. One account of these Cold War operations describes a typical operation of the 1950s in which an SA-16 Albartross flew in low under Soviet radar in order to land at night on an isolated lake 
in the Balkans to pick up and drop off agents. Such operations continued into the 1960s with the Soviets not suspecting that their airspace was being invaded by the CIA/USAF (Haas 1997: 119-120). The success of the special operations airmen in penetrating Sovietcontrolled airspace is a testament to the exceptional piloting and navigation training of the small special operations forces.

During the Cold War one of the most difficult of the USAF special operations with the CIA was the campaign to support the Tibetan guerrilla army that waged a decade-long war to oppose the Chinse invasion of their country which began in 1950 . This operation was highly sensitive in that the CIA and US Air Force had to use bases in allied nations such as Thailand and the mission required overflying neutral countries such as Burma and Nepal. Supporting the Tibetan guerrilla army, which grew to an 80,000-man force, required exceptionally long-range flights over some of the worst terrain in the world. The region between Thailand and Tibet was largely unmapped jungle and mountains. The area was also beset by sudden storms that hit with terrific force. Because the operation was so sensitive and secret there could be no network of emergency airfields, nor could the USAF mount a search and rescue effort if a plane went down. Of course, there were no navigation aids to help the American airmen navigate over endless jungle and then over some of the highest mountains in the world.

The Tibetan operation revolved around flying arms and supplies to the guerrillas as well as flying back to Tibet guerrillas who had undergone training in secret US military facilities outside Tibet. The initial missions to supply the Tibetans used the C-118 transport: a good plane for the time but with a relatively small payload, which limited the supplies and arms that could be flown into Tibet. In 1957 the USAF assigned some C-124 Globemaster transports to fly to Tibet and fly out Tibetans for guerrilla training. The USAF dramatically improved its ability to support the Tibetans when some of the first models of the C-130 
transport were assigned to the special operations forces for the Tibetan mission. With the C130 the special operations units supporting the CIA-led effort had an aircraft with the performance and payload to be truly effective.

The year 1959 saw one of the most dramatic episodes of the CIA/USAF operation when the US-trained Tibetan guerrillas (who had been flown back to Tibet after training outside the country) helped the legitimate spiritual and state leader of Tibet, the Dalai Lama, to escape the careful watch of the Chinese Army and make his way for hundreds of miles through tortuous mountain passes to the Indian border. The Dalai Lama was guarded by the US-trained and equipped guerrillas and he and his escort were sustained by supply drops by the C-130s that enabled his successful escape from the communists (Haas 1994: 28-31).

The Tibetan operation ended in May 1960 when a large force of the Chinese Army was deployed to Tibet to crush the insurgency. The Chinese pressure against the Tibetans became so overwhelming that continuing the resistance against the Chinese invaders was considered hopeless (Haas 1994: 31). Still, for a decade the CIA/ USAF partnership played a key role in enabling the Tibetan resistance. The Tibet operation, more than any other Cold War operation, demonstrated the ability of the USAF to support the clandestine operations of the intelligence service, even under incredibly difficult conditions. Remarkably, the USAF lost no transport aircraft during the Tibetan operation. The loss of any transport would have resulted in a diplomatic incident with several countries. This amazing record is testimony to the exceptional planning and training of the small USAF special operations units.

\section{Vietnam: the first true interagency operations}

The Vietnam War pushed the concept of interagency operations to a new level. In Vietnam, the United States found itself fighting two wars: both of which it had to win. The first war 
was against the conventional forces of North Vietnam, and required the military services to fight the kind of battles for which they were trained and equipped. The second war was broader, and harder to define. This was the war against the Viet Cong guerrillas, who lived and operated among the mainly rural population of South Vietnam. While the Viet Cong had a cadre of full-time leaders and some regular forces, many of the Viet Cong were part-time guerrillas who carried on their lives as peasants, but were also ready to conduct small-scale operations: setting ambushes, deploying booby traps, assassinating government officials, and harassing the government troops. The Viet Cong operated in a largely friendly environment with many South Vietnamese willing to provide the Viet Cong with information, food, and shelter. Other South Vietnamese were coerced into paying taxes and providing supplies to the Viet Cong.

While the conventional war against the North Vietnamese was the main focus of the US military, defeating the Viet Cong required a host of non-military resources focused on supporting the South Vietnamese civil government in the rural areas. The US campaign in the countryside included executing aid programs to improve farming and small business, advising and supporting the South Vietnamese civil agencies, providing basic services and medical care, improving the local infrastructure, and conducting a pro-government propaganda campaign. The US aid programs required civilian expertise and leadership, which they found in civilian agencies such as the US State Department, the CIA, and the US Information Agency. At the same time, the civilians had to work closely with the corps of military advisors who were responsible for standing up and training the South Vietnamese local security forces.

By 1967 , with the conventional military effort in South Vietnam expanding, the war against the Viet Cong was going poorly. The Viet Cong, who had created a very effective shadow government, was rapidly expanding its recruitment and influence. The weakness of 
the South Vietnamese government and its police and local self-defence forces allowed the Viet Cong to effectively control large parts of the countryside (Hunt 1995: 6-7).

The US military leadership under command of General Westmoreland (Commander, Military Assistance Command Vietnam (MACV)) understood that the military was unsuited to coordinating a mainly civilian-focused effort in the countryside. The answer to the problem was provided by a senior CIA officer, Robert W. Komer, who proposed a single agency combining military and civilian personnel to manage the American support of the South Vietnamese in the countryside. In 1967 the United States created CORDS (Civil Operations and Revolutionary Development Support), with Komer as director. At every level the rural pacification effort would be under one person, with civilian and military personnel intermixed. CORDS developed into a highly effective interagency organisation to support the South Vietnamese effort in the countryside. The agency came to oversee the South Vietnamese regional forces, psychological operations, public administration, and rural health care. The CORDS program, through effective coordination of effort, played a central role in breaking the power of the Viet Cong in the countryside. Viet Cong membership declined between 1968 and 1972, and the Viet Cong in guerrilla units declined from 77,000 in January 1968 to 25,000 in May 1972 (Hunt 1995: 252-253). As the Viet Cong declined, the government presence in the countryside improved, as did the security and living standards of the rural population.

Creating CORDS was no easy process, and the CORDS organisation exhibited problems that would bedevil all interagency organisations that came after. In eessence, CORDS was more of a coordination system than an independent agency, since it did not have its own resources. The State Department provided personnel and funding via its aid budget, and the military provided personnel, equipment, and funding for programs to develop the local South Vietnamese security forces. The CIA provided personnel as well. Considerable 
friction occurred at first in an organisation where many State Department and CIA civilians came under the direct command of military officers, while many military personnel ended up being commanded by civilians. However, Robert Komer proved an effective leader and made the new organisation work.

During the critical period after the Tet Offensive, CORDS took over the entire effort to develop and train the South Vietnamese regional and part-time forces tasked with local security in the rural effort. This included managing the advisory effort and working with South Vietnamese officials at every level. It was a difficult task in that the CORDS personnel could influence the South Vietnamese, yet not directly command them. Still, the effectiveness of CORDS in carrying out its mission cannot be denied. In the years 1968 until the American departure from Vietnam in 1973, the security situation in the countryside dramatically improved. In the spring of 1972, when the North Vietnamese Army (NVA) mounted a major offensive, the South Vietnamese regional forces, trained and advised by CORDS personnel, performed far better than they had during the 1968 Tet Offensive. Whereas the Viet Cong irregular forces had been a centerpiece of the 1968 campaign, in the 1972 offensive the Viet Cong played only a minor role. In contrast to 1968 , in 1972-73 the rural areas of South Vietnam were mostly under clear control of the South Vietnamese government.

Air power is part of the CORDS story in that CORDS, while a mixed military and civilian agency, reported to MACV and ultimately came under the command of the military theater commander. This meant that CORDS received air transport support from the USAF, a necessity for maintaining small CORDS teams in isolated areas of South Vietnam. Being tied into the MACV chain of command and communications net meant that CORDS provincial advisors, both civilians and military, could call in American and South Vietnamese air strikes in case of an NVA or Viet Cong attack. 
The ability of the CORDS personnel to call for air strikes played a key role in the defeat of the 1972 North Vietnamese Spring Offensive. Since nearly all the American combat ground troops had been withdrawn from Vietnam by 1972, the NVA believed that the time was right for a major ground offensive. Instead of fighting the American forces that had decimated the Viet Cong and North Vietnamese forces during the 1968 Offensive, the NVA would now face only the South Vietnamese Army and the regional forces - forces they had easily beaten in the past. However, thanks to CORDS, the South Vietnamese forces were better trained and prepared than in the past, and CORDS personnel could still call on the very considerable American air power still available in the theater. The combination of effective South Vietnamese forces, backed up by US air power and often coordinated through CORDS provincial advisors, proved deadly to the North Vietnamese. Despite conducting a massive effort that included tanks and heavy artillery, the NVA managed to overrun only one South Vietnamese provincial capital - and this was later retaken (Wilbanks 2004: chap 6).

With the NVA's bloody setback in 1972 and the improvement of South Vietnam's security situation, the US could negotiate a withdrawal of its forces from Vietnam in early 1973, turning the war effort over to the South Vietnamese. Unfortunately, in early 1975 the North Vietnamese initiated a massive conventional invasion of South Vietnam, spearheaded by large armored and mechanised forces backed up with heavy artillery and a mobile layered air defence system. Unable to cope with a true blitzkrieg by regular forces, the South Vietnamese military collapsed - and with it, the entire country.

Ironically, despite the myth that the United States is not effective in counterinsurgency operations, the Americans and South Vietnamese had actually crushed the guerrilla insurgents of the Viet Cong and secured the countryside for the government by 1972 - and CORDS deserves a great deal of the credit. Yet, in the aftermath of Vietnam, few in the US government wanted to look at the positive lessons that came from the war - and the 
CORDS interagency model was one of the real successes of the Vietnam War. It would be two decades before the interagency concept would be revived to fight a new kind of war.

\section{The Joint Interagency Task Force and the war on drugs}

With a crime epidemic at home that was fueled by drugs and the drug trade, and with major [entire?] nations such as Colombia and Peru becoming destabilised by the drug trade, it was clear by the early 1990s that something different from the traditional law enforcement model was needed to face a crime problem with major international implications. It is not that there was no effort being devoted to the war on drugs. The Drug Enforcement Agency (DEA), Border Patrol, Federal Bureau of Investigation (FBI), and Coast Guard were all involved in countering the drug trade.

The CIA and military provided intelligence, while the State Department oversaw aid to Latin American police forces. Yet despite a major effort by US law enforcement agencies the problems continued. Congress, concerned about the continuing rise of the drug trade and its destructive cartels, held hearings to see if a better use could be made of the efforts by the federal law enforcement agencies. One obvious problem was the lack of coordinated effort by the many agencies involved. As explained by Coast Guard Rear Admiral Andrew Granzuno and echoed by a host of senior officers in US Congressional hearings, 'There is no one in charge' of the drug interdiction campaign, and this was a key factor to drive some radical changes [insert source?]. Another factor encouraging a more concerted effort was the change made by the US government in looking at the drug trade as an international security issue. Indeed, by the early 1990s, the focus in the war on drugs turned to interdiction (reducing the supply), and this meant going after the production and distribution of the drugs at their source 
and not just dealing with the drugs later as a law enforcement or border protection issue (Presidential Decision Directive PDD14 1996).

With this new national security focus, the US government turned to the interagency concept that would become the key tool in fighting international drug trafficking. In 1994 President Clinton signed Presidential Decision Directive 14, National Drug Policy, that set up three US Joint Interagency Task Forces (JIATFs) responsible for the Latin American, Caribbean, and Pacific regions and would serve as organisations specifically designed to coordinate the counterdrug and interdiction operations. In 1997, as the US pulled forces out of Panama to comply with the turnover of the Panama Canal, the JIATF South (headquartered in Panama) was combined with the JIATF East (headquarters in Key West, Florida) and renamed Joint interagency Task Force-South. The J IATF was an entirely new organisation for the United States and was designed to formally integrate personnel and capabilities of the US military, the US Coast Guard (Department of Transportation), the Customs Service (Department of the Treasury, the DEA (Justice Department), the FBI (Justice Department), and intelligence agencies such as the CIA, National Security Agency (NSA), and Defense Intelligence Agency (DIA). Because the Caribbean region also included the overseas territories of America's NATO allies France, the UK, and the Netherlands, those countries also became involved with the JIATF South.

The JIATF for the counter-drug campaign had a carefully designed command and organisational structure that required the full integration of the civilian agencies and military. For example, the largest of the JIATFs, JIATF South (responsible for the Caribbean region, is commanded by a Coast Guard rear admiral. This makes sense, as the US Coast Guard itself is a hybrid organisation, serving not only as a US military force but also having civilian duties in regulating and policing shipping. While the Navy, as a military force, is not normally tasked with law enforcement duties the Coast Guard is, and Coast Guard personnel, unlike 
Navy personnel, have arrest authority and are well trained in the duties of enforcing the law at sea. Other sections of the headquarters are allotted to other services and agencies.

The deputy commander is a US Navy rear admiral, the vice director is a senior Customs Agency officer, another vice director is a senior FBI agent, and the chief of staff of the JIATF South is a US Air Force colonel. The headquarters looks much like a military command with a J-2 Intelligence section, a J-3 Operations section, a J-4 Logistics section, and a J-5 Plans section. However, the JIATF also has sections not found in a normal military organisation, to include a J-9 International Affairs section. Because of the nature of its mission the JIATF South contains specialist liaison officers from the military and intelligence services and also from foreign allies - namely the Dutch, British, and French who provided naval and air units to support the task force.

The heart of the JIATF is the operations command center where the intelligence and operations are fully integrated. The Task Force is able to access and analyse intelligence from every source: human intelligence, signals intelligence, imagery intelligence, and air and space surveillance. Intelligence is provided through the Task Force's own assets, but mainly through direct liaison with law enforcement agencies and military commands. The Air Force liaison officer, for example, can request Air Force Space Command's support for imagery and surveillance. In the intelligence center of the Task Force civilians and military personnel are fully integrated into functional teams. Monitoring shipping and air traffic, for instance, one might find a Marine sitting next to an Air Force NCO with a DIA civilian serving as the section leader. JIATF South has its own resources to mount operations, with naval and Coast Guard vessels, military aircraft, military and law enforcement personnel organised into three task groups to operate in sectors of the Caribbean. Allied nations are full partners in the mission, with a flag officer from the Netherlands commanding one of the task force groups involved in patrol and drug interdiction. French and British air and naval and police forces 
also participate in the task groups (Marine Nationale 2011). However, if the situation requires more assets and assistance the JIATF can, as a military organisation, access available military units to support specific operations.

Air power plays a central role in the work of the JIATF, mainly in the form of air and space reconnaissance and surveillance of the vast region. Once a likely drug shipment by sea or air is identified, air assets track the suspicious vessel or aircraft and often helicopter units are employed in the interdiction and seizure of drug shipments. For this reason the chief of staff slot is filled by an Air Force colonel, and Air Force liaison and intelligence personnel are assigned to the command center. Other Air Force assets are integrated into the Task Force's three groups.

In the more than two decades since the JIATF South and West were developed, they have demonstrated their value in integrating military and civilian agency assets, as well as foreign forces, into one highly efficient organisation. The JIATF South and West did not end the drug trade, but their work did noticeably increase the amount of drugs interdicted and the number of drug smugglers arrested. They have forced drug cartels to move to new, less efficient transport routes and have put pressure on the insurgent forces that used the drug trade as their means of finance and support. Colombia and Peru are far more stable nations since the more effective counterdrug strategy of the 1990s, and the JIATFs can take some of the credit.

\section{Air power and the JIATF in the war on terror}

The international interventions of the 1990s highlighted the need for military and civilian agencies to work together more effectively. The end of the Cold War did not bring the expected era of peace, but instead unleashed a high level of international disorder. The 
implosion of various countries required international intervention led by military forces. These types of operations had been conducted before, but usually on a limited scale. However, the 1990s saw a series of crises erupt from Africa to Latin America to Europe and each crisis required a strong military response initially, with a strong follow-on response from civilian agencies to stabilise the country affected and assist it to restore services and government functions. In most cases these interventions required first dealing with large numbers of refugees and whole communities in dire need of medical aid and food. In the 1990s both the US-led interventions in Panama (1990) and Haiti (1995), and the NATO-led interventions in Bosnia (1995) and Kosovo (1999), required the deployment of significant numbers of military personnel, accompanied by aid workers and civilian agencies from supporting governments, or put under contract by the United States and NATO. The interventions in Haiti, Bosnia, and Kosovo required long periods to stabilise the chaotic and lawless conditions and to assist the local populations to return to a stable civilian life.

Neither the United States nor the European nations had an effective interagency doctrine or organisation to provide the command and control for military and civilian government agencies to operate together. The lack of a military/civilian command and control system meant that various ad hoc systems were thrown together that, frankly, did not work effectively. In the case of the US interventions in Panama and Haiti the US State Department, which oversees aid to foreign nations as well as law enforcement training missions, was completely unprepared to support the oversight and training of local law enforcement, was unready to assist in the rebuilding of government and other nation-building measures. The immediate distribution of food and provision of emergency health care was successful, but the long-term stability operations remained a problem (Pope 2014: 79-81). Part of the problem was rivalry and competition between agencies, exacerbated by insufficient planning and resources for sustained aid to government. 
As in the early years of the war on drugs, it was often unclear who was actually in charge. The National Security Council, charged with ensuring that military and civilian agencies are coordinated at the strategic level, failed to work out any effective command and control for military and civilian agencies (Pope 2014: 57). Unfortunately, the later military/civilian stability operations in Iraq and Afghanistan were still carried out with an ad hoc command and control system as multiple agencies led separate efforts with little overall coordination (Pope 2014: 84, 90). Another study of the problems in military/civilian agency coordination in the 1990s and into the 2003 Iraq War pointed out the friction over the roles of the agencies in stability operations as these were not clearly defined. Without a clear direction from the top (National Security Council) the agencies were left without clear lines of command and authority in conducting vital missions (Rast 2004: 247-248). In short, the US military and civilian leadership were still struggling with a model of how to coordinate military and civilian efforts.

Fighting the global terrorist network of al-Qaida after 2001 became a top priority of the United States. With al-Qaida and allied radical Islamist factions the Americans were dealing with a new kind of enemy. Not only were America and Coalition partners facing local insurgents in Afghanistan and Iraq, but in Iraq the Coalition forces faced well-trained and financed foreign fighters who had flocked to Iraq to join the local factions fighting the Coalition forces trying to stabilise the country in the aftermath of the 2003 conventional war that toppled Saddam Hussein's regime. Many of the foreign fighters joined a force called alQaida in Iraq under the leadership of a Jordanian jihadist, Abu Musab al-Zarqawi. The professional jihadists took advantage of the chaotic situation in Iraq to increase the level of violence and to push Iraq into a full scale Sunni-Shia civil war that would have ended any hope for a stable nation. 
Al-Qaida in Iraq could call on the global network of al-Qaida for support and legitimacy. Early in the conflict the United States responded by setting up a Special Operations task force, Task Force 714, directed to conduct operations against al-Qaida and its leadership throughout the area of responsibility of Central Command (CENTCOM). However, it was soon clear that far more than special operations and the military intelligence assets would be needed to fight a sophisticated international enemy that operated underground and worked through a network of small groups.

In 2004 Task Force 714 was reorganised as a JIATF that would include not only military personnel from all the services, but also civilian personnel from the CIA and DIA. As with the JIATFs conducting the drug interdiction campaign, the civilian and military intelligence personnel were fully intermixed in functional teams and CIA paramilitary and support personnel were integrated into the operational and support forces. Again, as with the anti-drug interagency task forces, the intelligence and operations centers were combined into one large operations center. This meant that priority intelligence information developed by the collection and analysis teams could be passed on to operations immediately. While often missions were conducted after a careful planning process, in war conditions the intelligence acquired sometimes demanded immediate action; otherwise opportunities to capture or kill terrorist leaders and groups might be lost.

The United States set up two interagency task forces to focus on different parts of the war on terrorism. JIATF East was based at Bagram Air Base in Afghanistan and focused on al-Qaida leadership in Central Asia. JIATF West was based at the huge Balad Air Base forty miles north of Baghdad and focused on fighting the al-Qaida forces in Iraq. Both were under the direction of General Stanley McChrystal, a highly experienced special operations officer who had a knack for unusual missions. In his memoirs General McChrystal described the long process of building the JIATFs into effective teams that could process large amounts of 
intelligence and act quickly upon it. Like the counter-drug interagency task forces, the JIATF in Iraq had its own Special Forces units assigned to it, but the effective liaison with the other services also meant that air and ground units in the theater could be immediately tasked for missions. Air power provided an essential capability to the JIATF West in the form of surveillance through aircraft and mostly unmanned aerial vehicles, whose long endurance provided the capability to observe and follow targets for twelve or more hours at a time. When raids were required helicopter-borne special operations teams were at hand and aircraft could be tasked at a moment's notice. Starting with a very limited intelligence picture of Iraq and the al-Qaida threat, by 2005 the JIATF West was becoming effective in developing focused analysis that gave the Coalition Forces an accurate view of the terrorist networks. This intelligence enabled the strike forces to take down key parts of the al-Qaida organisation (McChrystal 2013).

A key event in June 2006 demonstrated the worth of the and the importance of air power in the surveillance and strike roles. The leader of al Qaeda in Iraq had long been the main target of JIATF West. One mullah known to be a close advisor of al Zarqawi and to meet with him regularly was put under surveillance by an umanned aerial system (UAS). A young civilian analyst working on the surveillance team noticed the mullah moving out with several associates. Immediately the other surveillance teams were alerted and strike forces put on standby. Other surveillance aircraft were diverted immediately to support this high priority mission. Al-Zarqawi’s mullah drove some distance from Baghdad and met alZarqawi in a small restaurant.

Two groups emerged and climbed into two vehicles which took off in different directions. Helicopter-borne Special Forces teams intercepted one vehicle and captured the drivers, but they were low level operatives. The other vehicle with the mullah/advisor took a side road to an isolated farm compound. Knowing that this was al-Zarqawi's headquarters 
and as it was nearing dusk, and would have required a large force to properly surround the compound at night, the decision was made to call in an F-16 air strike, which pulverised the farm house with two 500lb precision bombs. A Special Forces team arrived minutes later to find al Zarqawi dying as well as a trove of documents in the compound. The loss of al Qaeda's charismatic leader was a major blow to the foreign jihadi forces operating in Iraq. The strike on al Zarqawi showed how the JIATF, which fully integrated intelligence with operations and had the right mix of air assets available, could put a complex operation together with no notice and rapidly adjust the mission to achieve full success (McChrystal 2015: 130-131, 235-242). No other kind of organisation can employ this kind of flexibility and integrate air power so efficiently into operations.

\section{Conclusion}

Interagency operations have become one of the major tools in modern conflicts with irregular enemies. The interagency organisation has proven its worth as a means of effective command and control for air, ground and sea assets. Western nations will see extensive use of interagency operations in the future and air power will be a major part of these operations. However, in the years since the Cold War some key lessons have been learned about interagency operations. First of all, civilian and military agencies do not naturally work well with each other and one can expect considerable organisational friction in any interagency operation. Secondly, building an effective interagency organisation requires leaders who can understand civilian and military cultures and who are willing to work well outside their comfort zone to integrate different agencies into one well-running organisation. Third, ad hoc interagency organisations have not been effective. To use all the military and civilian assistance [participants? assets?] well and to ensure full cooperation from the participating agencies, the joint interagency task force needs to be clearly focused and have a clearly 
defined mission. The tasks of all the participating agencies have to be carefully spelled out to ensure clarity of the mission as well as ensure that the participating agencies fully support the task force.

\section{References}

Haas, M. (1994) Air Commando! 1950-1975: Twenty-five Years at the Tip of the Spear, Hurlburt Field, FL: Air Force Special Operations Forces.

Haas, M. (1997) Apollo's Warriors: United States Air Force Special Operations during the Cold War, Maxwell AFB, AL: Air University Press.

Hunt, R. (1995) Pacification: The American Struggle for Vietnam's Hearts and Minds, Boulder, CO: Westview.

Marine Nationale (2011) ‘Le Joint Interagency Task Force-South (JIATF-S)’, 2 January.

Online. Available HTTP: <http://www.defense.gouv.fr/english/marine/operations/zoom-surla-marine-en-outre-mer/la-lutte-contre-le-narcotrafic-aux-antilles/le-joint-interagency-taskforce-south-jiatf-s> (accessed 8 June 2017).

McChrystal, S. (2013) My Share of the Task, New York: Penguin.

McChrystal, S. (2015) Team of Teams, New York: Penguin. 
Moore, B. (1992) The Secret Air War over France: USAAF Special Operations Units in the French Campaign of 1944, Maxwell AFB, AL: Air University Press.

Pope, R. S. (2014) US Interagency Regional Foreign Policy Implementation, Maxwell AFB, AL: Air University Press.

Presidential Decision Directive PDD14 (1996) National Drug Policy: A Review of the Status of the Drug War, Committee on Government Reform and Oversight, 19 March.

Rast, V. (2004) Interagency Fratricide: Policy Failures in the Persian Gulf and Bosnia, Maxwell AFB, AL: Air University Press.

Wilbanks, J. (2004) Abandoning Vietnam, Lawrence, KS: University Press of Kansas.

Y'Blood, W. (2014) Air Commandos Against Japan: Allied Special Operations in World War II Burma, Annapolis, MD: Naval Institute Press. 